\author{
高強度レーザー用反射型波形整形システムと \\ 周波数分解光ゲート法によるその特性評価 \\ 伊藤 晴康，浦上 恒幸，吉田成浩，伊ヶ崎 泰則，細田 誠 \\ 浜松ホトニクス株式会社 中央研究所（干434-8601 静岡県浜北市平口5000)

\section{Reflect-Type, Highpower-Laser Pulse Shaping System and its Operation Verified by Frequency Resolved Optical Gating}

\author{
Haruyasu ITOH, Tsuneyuki URAKAMI, Narihiro YOSHIDA \\ Yasunori IGASAKI, and Makoto HOSODA \\ Central Research Laboratory, Hamamatsu Photonics K.K., 5000 Hirakuchi, Hamakita, Shizuoka 434-8601
}

(Received February 14, 2000)

\begin{abstract}
We demonstrated reflect-type pulse shaping of high-power femtosecond pulses from a Ti:sapphire regenerative amplification system that generates $4.0-\mu \mathrm{J}$ pulses of less than $70-\mathrm{fs}$ pulsewidth at a $250-\mathrm{kHz}$ repetition rate with an average power of $1.0 \mathrm{~W}$. The PAL-SLM (Parallel Aligned nematic Liquid crystal Spatial Light Modulator) contained in our pulse shaping apparatus was evaluated and was able to modulate high peak power pulses up to $2.4 \times 10^{7} \mathrm{~W}$. As a result, the pulse shaping system was used to generate high-power double pulses, as was confirmed by FROG (Frequency Resolved Optical Gating).
\end{abstract}

Key Words: Femtosecond pulses, Frequency resolved optical gating, Pulse shaping, Spatial light modulator

1.はじめに

近年,チャープパルス増幅技術の発展に伴い, 高強度フェ ムト秒レーザーが実現され，テラワット以上のピークパ ワーを持つものも可能となってきた1)。このようなレー ザーによる光相互作用では, 例えば,フェムト秒アブレー

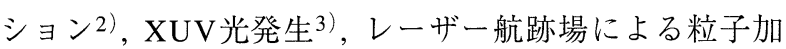
速4), 核融合による中性子発生5)等, 種々の新しい現象が興 味を引きつつある。これら現象の多くは超短光パルスの 非常に強い光電場によって生起するため, 光電場自身の振 幅のみならずチャープも含めた波形整形により,現象の発 生効率向上やコヒーレント制御等を行える可能性があ る、しかしながら,これまで波形整形技術6,7) は弱いフェム ト秒パルスに対しての報告.(例えば,半導体量子井戸におけ る励起子の生成消滅や $\mathrm{THz}$ 波発生をコヒーレント制御する 手段として使用された報告8,9) ${ }^{8}$ はあるが, 高強度フェムト 秒パルスに対して適用された例は少ない10)。これは高強 度レーザーに対する波形整形器の耐性や, その構成が明確 にされていないためと考えられ，それに対する実際の適用 例を報告することは価值があると考える．筆者等は, 波形 整形された高強度光パルスと物質との相互作用制御を目 的として, 高強度光パルスの波形整形および波形観測シス テムの開発を行っており,本論文では実際に試作したシス テムの特性評価を行ったので報告する。

\section{2. 実験装置}

2.1 マルチショットFROG (Frequency Resolved Optical Gating)

波形整形が正常になされたことをモニターするために は超短光パルスの振幅と位相とを正確に把握する必要が ある．超短光パルスの振幅と位相を計測する手法として は, IRIS法 ${ }^{11)}$, FROG法 ${ }^{12)}$, SPIDER法13)等があげられるが, 筆者等は中でも簡便かつ高感度の計測が可能なFROG法を 用いた. FROG法は, 位相回復法を非線形相関計測に取り 入れた手法であり,非線形相互作用としては偏光ゲート,自 己回折, SHG, THG等が用いられる.この際, 自己相関系の 遅延時間を变えながら非線形相互作用により得られる光 を分光計測することにより縦軸スペクトル, 横軸遅延時間 の2次元の像 (以下FROG像)が得られ, この像を解析してパ ルス波形の再構築を行う。筆者等は, 後述する波形整形器 のモニター光計測に用いるため, 前記非線形相互作用の中 で最も高感度な計測が可能なSHG-FROGを選択し, それを 自作した. Fig.1に試作したSHG-FROGの概略図を示す。 前段の自己相関系では, 光学素子の分散による影響を避け るためにハーフミラー以外は全て金蒸着ミラーによる反 射光学系を用いた. 集光用凹面鏡の曲率半径は $150 \mathrm{~mm}$ あり, SHG結晶には厚さ $300 \mu \mathrm{m} の \mathrm{BBO}$ (浜松ホトニクス製, X7521)を用いた。 また, 分光器の構成はツェル・ターナー 型とし,スリット幅を $50 \mu \mathrm{m}$, 凹面鏡の曲率半径を $250 \mathrm{~mm}$ と 


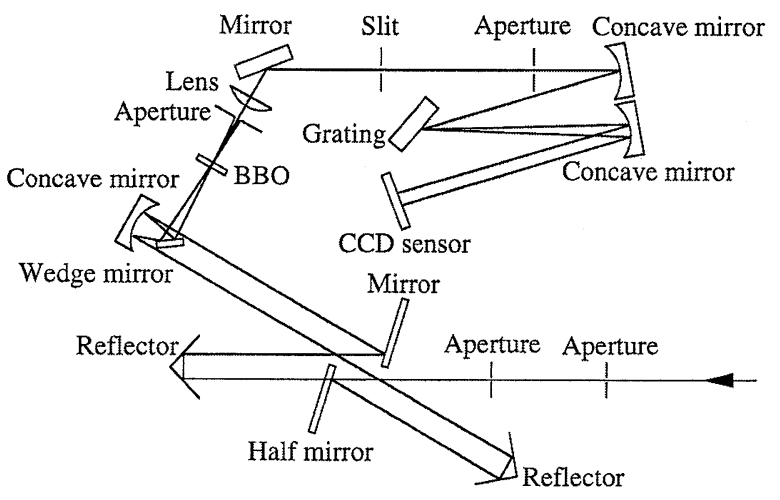

Fig.1 Multi-shot SHG FROG.

することにより, $0.5 \mathrm{~nm}$ 以下の分解能が得られている。一 方, 検出器には裏面入射 CCD (浜松ホトニクス製, S70300906）を用いている，裏面入射CCDは90\%以上の量子効率 が得られると共に,UV域での高感度を特長とする微弱光検 出用イメージセンサであるため, SHG-FROGに適した検出 器である. 前記検出器からのデー夕を遅延時間約13.3fs テップ(遅延距離 $2 \mu \mathrm{m} \times 2$, 最小分解能 $1 \mu \mathrm{m} \times 2$ )にて 128 回 取得し, $128 \times 128$ のデータから波形を再構築する. 以上よ り,このFROGでは例えば, $\mathrm{CCD}$ 蓄積時間を 5 秒, 積算回数を 1 回として, 繰り返し周波数 $96 \mathrm{MHz}$, パルス幅60fs, 中心波長 $790 \mathrm{~nm}$ の光を計測する場合に必要とされる最小光強度は $30 \mu \mathrm{W}$ という高感度性が達成され, 低強度から高強度まで の広い範囲における波形整形システムの特性評価が可能 となった。

2.2 高強度レーザー用平行配向ネマチック液晶空間光 変調器

波形整形器では, グレーティング等を用いて入射光を フーリエ変換し, フーリエ成分が空間的に展開されたフー リエ面上で空間光変調器により変調を加え, その後逆フー リエ変換することにより整形された光パルスが得られ る.この空間光変調器には, 一般的には電気信号アドレス 型の素子が用いられるが, 電極パターンなどの画素構造に よる回折光が発生して位相変調パターンに歪みが生じた り, 開口率による光利用効率の低下といった問題が懸念さ れる.

これらの問題を解決するために, 筆者等はFig.2に示され るPAL-SLM(Parallel Aligned nematic Liquid crystal Spatial Light Modulator, 浜松ホトニクス製, X7665) ${ }^{14)}$ を変調素子 として用いた. PAL-SLMでは, 光アドレス材料である水素 化アモルファスシリコン $(\alpha-\mathrm{Si})$ に照射される書き込み光 (変調パターンに対応した空間パターンを有する光)の強度 に応じて $\alpha$-Siの抵抗が変化, すなわち液晶部分に印加され る電圧が変化し,これに伴って読み出し光(波形整形器への 入射光)が位相変調される。また, PAL-SLMと電気アドレ ス型の液晶デイスプレイ $(\mathrm{LCD})$ を光学伝達素子で結合す るモジュール(浜松ホトニクス製, X7550) ${ }^{15)}$ を用いること により,パソコンの画面と一対一に対応した2次元的な変調 が可能となっている.このモジュールにおいては,パソコ ンで作製されたVGA $(640 \times 480$ 画素) 256階調画像がLCDに

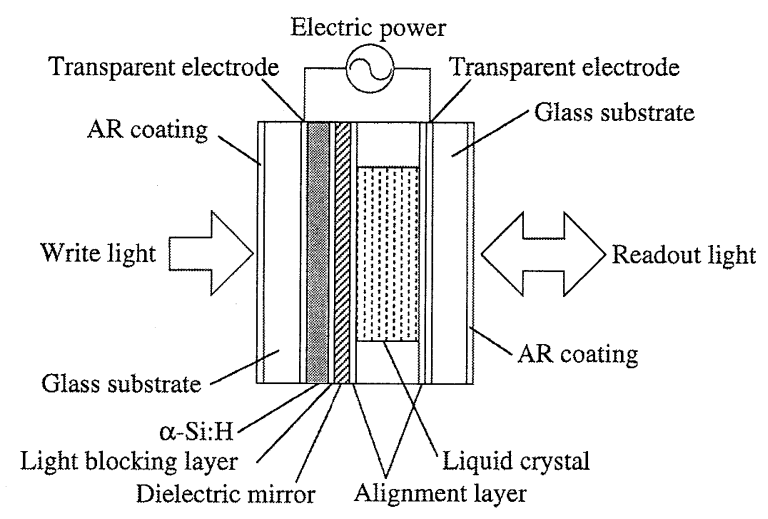

Fig.2 Structure of PAL-SLM.

表示されると共に,このLCDを透過したLDコリメート光が SLMに結像され, その結果前記画像に応じた書き込み光の 強度パターンが得られる。使用したPAL-SLMでは約 $210 \mu \mathrm{W} / \mathrm{cm}^{2}$ の書き込み光強度, 画像レベル193階調に対して $2 \pi$ の位相変調量が得られる。ただ, 従来のPAL-SLMは低 強度の読み出し光を対象として設計されていたために, 高 強度の読み出し光を用いた場合には誘電体多層膜鏡から の漏れ光が書き込み光に重畳し, 設定通りの変調が得られ なくなり, 整形が正常に行われなくなる。そこで筆者等 は, 空間光変調器として高強度耐性PAL-SLMを用いた波形 整形器の構築を試みた。このPAL-SLMでは, 高強度のレー ザー光に対しても前述の問題が生じない様に誘電体多層 膜鏡と $\alpha$-Si との間に従来より吸収率の高い遮光層が配置さ れている。実際にTi:sapphire再生増幅システム (パルス幅 約70fs)より得られる高強度のレーザー光を用いて耐光強 度特性を評価した. Fig.3に示す波形整形器の出力側グ レーティングの位置にグラン・トムソン偏光プリズムお よび光パワーメーターを配置した状態で, SLMの印加電圧 を一定として入射光量を変化させた場合の位相変化を Fig.4に示す. 尚, レーザー光の偏光は紙面に対して水平と

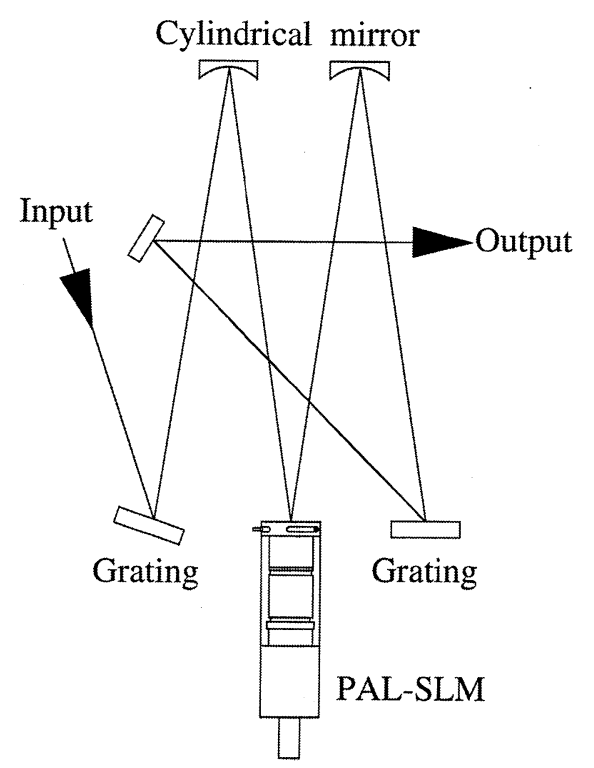

Fig.3 Pulse Shaper. レーザー研究 2000 年 8 月 


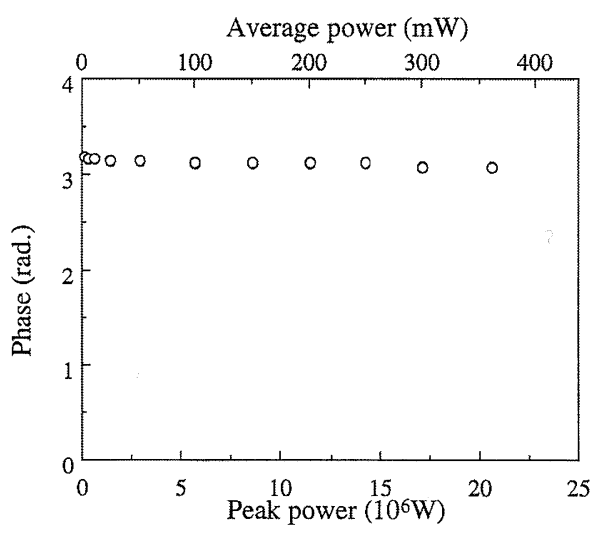

Fig.4 Phase variation versus input power.

し, SLMの配向方向がレーザー光の偏光に対して45度の角 度をなす構成とした. Fig.4より, 改良後のSLMでは再生増 幅された光程度では漏れ光の影響がほとんど観測されな いため,十分に波形整形が可能であることが確認される。

\section{3 反射型波形整形器}

高強度フェムト秒光パルスを用いる場合, 光学素子等に おいて発生する位相分散, 自己位相変調および透過型素子 の損傷が問題となる. 波形整形においても例外ではなく, これらの問題を避けるために反射型構成のシステムを構 築した. Fig.3に示される波形整形システムでは, 光学素子 の分散による影響を避けると共に, 装置の小型化を図るた めに曲率半径700mmのシリンドリカルミラー(低分散誘電 体多層膜蒸着) および前述した反射型空間光变調器を用 い,さらに光のロスを避けるために位相変調だけを用いて 整形を試みた.オシレーターからの光を直接用いる場合に は, 平凹レンズ $(f 50)$ および平凸レンズ $(f 200)$ から構成さ れる拡大光学系によりビーム径を拡大する. 一方, 後述す る増幅された光を用いる場合には波形整形器に入射する 段階でビーム径が拡大されているために, 直接波形整形器 に入射する．グレーティングへ入射する光のビーム径を 拡大することにより, SLM上での波長分解能の向上が図ら れるとともに, 入射光がSLMの有効領域 $(20 \mathrm{~mm} \times 20 \mathrm{~mm}$, $480 \times 480$ 画素)の広範囲にわたって照射されるため, SLM の漏れ光の影響, および素子の損傷等が極力抑えられる. また, グレーティングは溝本数 830 本 $/ \mathrm{mm}$, ブレーズ波長 800nmのブレーズド・.ホログラフィック・グレーティング を用いており, 波形整形器入射光に対する出射光の透過率 は約40\%である。透過率が40\%と低いのは,グレーティン グの回折効率に依存しているためである。また前記構成 では, 20mmの領域に照射される波長範囲は約70 $\mathrm{nm}$ である ため, 被整形光パルスのスペクトルはこの範囲に制限され る.

波形整形された光をFROGにより計測する場合は, FROG 前段に平凹レンズ ( f 50) および平凸レンズ $(f 200)$ から構成 される縮小光学系を配置し, ビーム径を縮小した状態で計 測する. 尚, 光学系にレンズ等種々の分散媒質が含まれて
いる場合には, 光パルスが分散を受けることになる. 本波 形整形器では,グレーティングとシリンドリカルミラーと の間隔を調整することにより前記分散を補正する。

2.4 分散媒質を用いたFROGおよび波形整形器の動作 確認

BK7ガラスの屈折率は以下に示されるセルマイヤー・ヘ ルムホルツの式によりあらわされる*.

$$
\begin{aligned}
n^{2}(\lambda)-1= & \frac{1.01237433 \lambda^{2}}{\lambda^{2}-5.88328615 \times 10^{-3}}+ \\
& \frac{2.58985218 \times 10^{-1} \lambda^{2}}{\lambda^{2}-1.90239921 \times 10^{-2}}+ \\
& \frac{1.00021628 \lambda^{2}}{\lambda^{2}-1.04079777 \times 10^{2}}
\end{aligned}
$$

一方, 光パルスの位相 $\phi(\omega)$ は中心角周波数 $\omega_{0}$ を中心

$$
\begin{aligned}
\phi(\omega)= & \phi\left(\omega_{0}\right)+\left.\dot{\phi}\left(\omega_{0}\right)\right|_{\omega=\omega_{0}} \\
& \times\left(\omega-\omega_{0}\right)+\left.\frac{1}{2 !} \ddot{\phi}\left(\omega_{0}\right)\right|_{\omega=\omega_{0}} \\
& \times\left(\omega-\omega_{0}\right)^{2}+\left.\frac{1}{3 !} \dddot{\phi}\left(\omega_{0}\right)\right|_{\omega=\omega_{0}} \\
& \times\left(\omega-\omega_{0}\right)^{3}+\cdots
\end{aligned}
$$

と展開される。このうち, 0 次の項は単純なオフセットであ り, 1次微分の項は時間軸方向のシフトをあらわすものであ る.したがって, 時間波形に变化を及ぼすのは2次微分以上 の項となるが, 3次微分以上の項は微々たる量でありパルス 幅100fs程度の光パルスの場合にはほとんど無視できる。 そこで, 2次微分の項だけを用いて長さ $L=250 \mathrm{~mm}$ のK7ガ ラスブロックの場合の位相遅延を計算すると, 光パルスは Fig.5に示す位相遅延を受けることになる．ただし，

$$
\ddot{\phi}(\omega)=\frac{\lambda^{3} L}{2 \pi c^{2}} \frac{d^{2} n(\lambda)}{d \lambda^{2}}
$$

である16).

この既知の位相遅延量を用いてFROGおよび波形整形器 の動作確認が行える。その概念図をFig.6 (a)〜 (c)に示

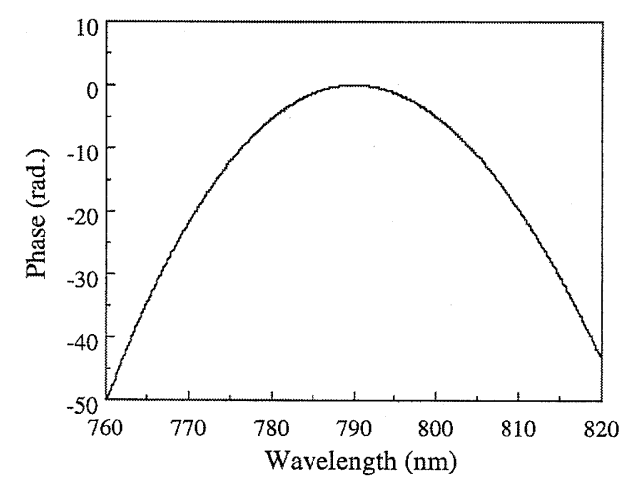

Fig.5 Phase distortion for BK7 glass (250 mm length).

\footnotetext{
* SCHOTT Optical Glassカタログ
} 


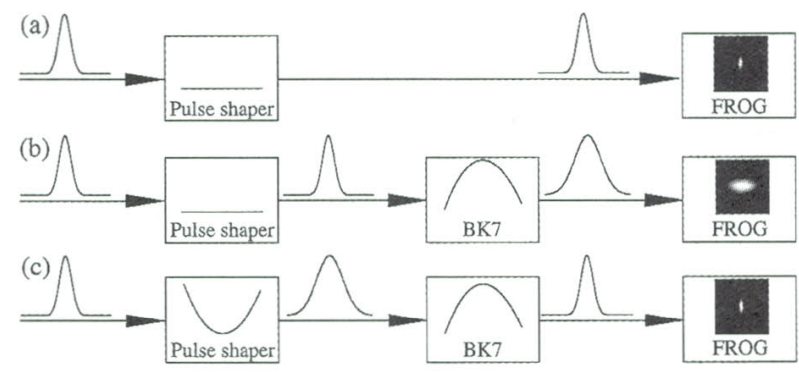

Fig.6 Experimental setup to evaluate the system.

す。まず (a)波形整形器の設定を無変調状態として再生増 幅をしない通常のTi:sapphireレーザー(Clark-MXR, NJA-4) 光がFig.3に示される波形整形器を伝搬した後の光パルス, および (b) 波形整形器の設定を無変調状態として波形整形 器伝搬後に長さ $250 \mathrm{~mm}$ のBK7ガラスブロックを伝搬した 後の光パルスの状態をFROGにて計測した結果をそれぞれ Fig.7 (a) 〜 (c) , およびFig.8 (a)〜 (c) に示す. 図中の (a)が FROG像, (b) および (c) が解析後のスペクトル波形ならび に時間波形である. Fig.5に示される理論值とFig.8 (b) に示 される実測值とが概ね一致している様子が確認され, FROGが正しく動作していることがわかる，さらに, 波形 整形器を用いてFig.5に示されるBK7ガラスブロックの位 相遅延の理論值と符号が逆の分散を与えて元のパルス波 形に整形し直したときに得られる光パルスの状態 (Fig.6 (c))を計測した結果をFig.9 (a)〜 (c) に示す. Fig.7とFig.9 とが概ね一致していることから, 波形整形器によってほほ 設計通りの位相変調が行われている様子が確認される.

\section{3. 高強度光パルスを用いた実験および結果}

Ti:sapphire再生増幅器システム (COHERENT, RegA 9000) から得られる高強度光パルスをダブルパルスに波形整形

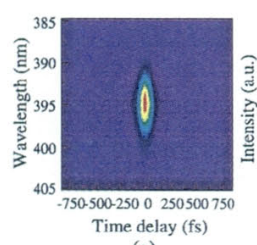

(a)

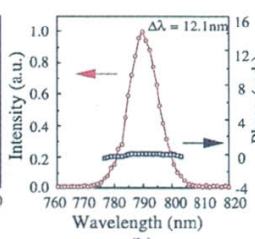

(b)

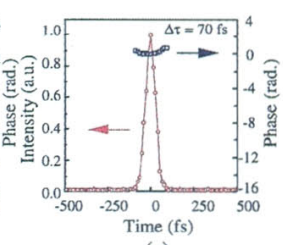

(c)
Fig.7 (a): SHG FROG trace of a pulse from a Ti:sapphire oscillator, (b): retrieved spectrum, and (c) temporal waveform and phase.

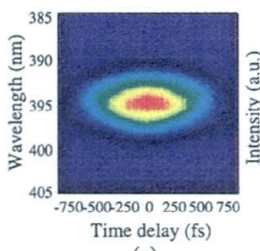

(a)

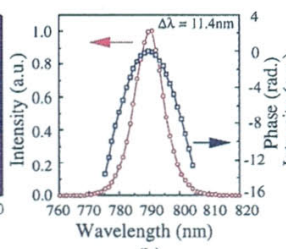

(b)

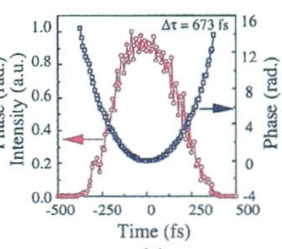

(c)
Fig.8 (a): SHG FROG trace of a chirped pulse from a Ti:sapphire oscillator, (b): retrieved spectrum, and (c) temporal waveform and phase.

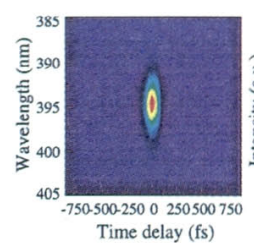

(a)

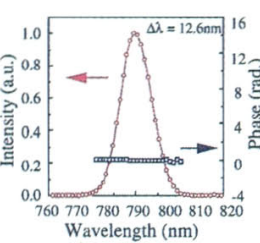

(b)

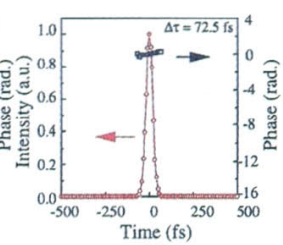

(c)
Fig.9 (a): SHG FROG trace of a compensated pulse from a Ti:sapphire oscillator, (b): retrieved spectrum, and (c): temporal waveform and phase.

した例を以下に示す。前記システムょり得られる光パル スのビーム径は,グレーティングに入射する時点で直径 $11 \mathrm{~mm}$ である。また, システムの繰り返し周波数は $250 \mathrm{kHz}$, パルス幅は65fs, SLMに照射される平均光強度は394mWで

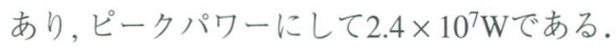

\section{1 高強度レーザー光使用時における波形整形器の動} 作確認

長さ250mmのBK7のガラスブロックを用いてシステム の動作確認の際に行った実験と同様な実験を行った．各 条件の下で得られる光パルスの状態をFROGを用いて計測 した際に得られたFROG像をFig.10 (a)〜 ( c) に示す. 尚, Fig.10 (b)に示される波形整形器の設定を無変調とした状 態でガラスブロックを伝播させた後の光パルスの状態が Fig.8 (a) に示される結果と異なるが, これは光学系に配置 されたレンズあるいはBK7ガラスブロック中において自己 位相変調が生じたことが原因と考えられる。

ガラスブロックによって生じる線形なチャープと同等 量の逆分散を与えたことで, 再度パルスが圧縮されている ので, 高強度光パルスに対してもSLMによる位相変調はか けられていることは確認される。たたし, 自己位相変調に よって生じたスペクトル歪みや広带域化を正しく補正し ているわけではないので, 完全にTi:sapphire再生増幅器シ ステムを出射した直後の状態に戻っているわけではな い.

\section{2 高強度レーザーのダブルパルスへの整形}

次に, 高強度光パルスのダブルパルスへの整形を試み た. 前記再生増幅システムより得られるほほトランス フォーム限界な光パルスを, パルス幅 $100 \mathrm{fs}$, パルス間隔 $500 \mathrm{fs}$ のダブルパルス $\left(\mathrm{sech}^{2}\right)$ に整形するための位相変調 フィルタをFig.11（a）に示す．位相フィルタの決定は, 簡易
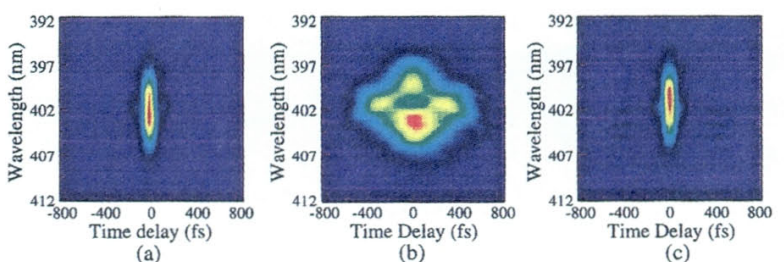

Fig.10 Experimental result for evaluation. (a): no phase modulation, (b): no phase modulation + BK7 (250 $\mathrm{mm})$, and (c): dispersion compensation + BK7 (250 $\mathrm{mm})$. 


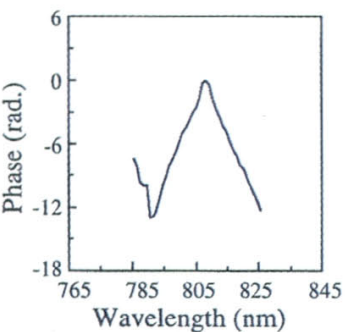

(a)

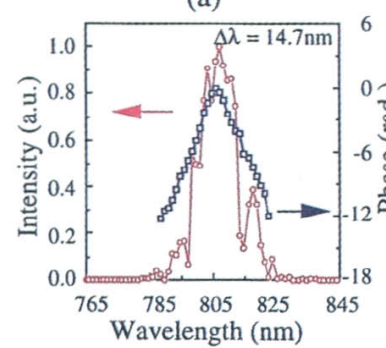

(c)

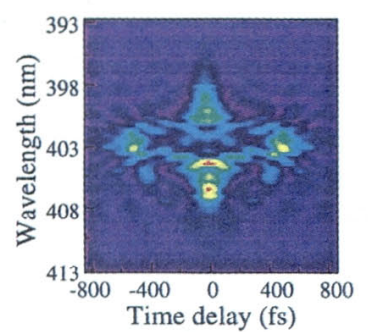

(b)

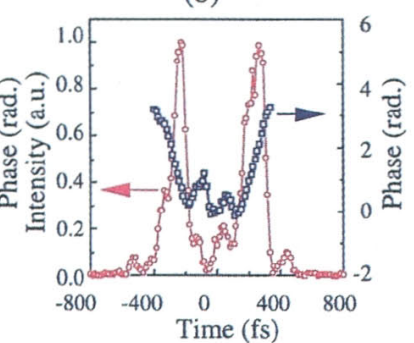

(d)
Fig.11 (a): Phase filter for double pulse.

的な決め方として以下の手順で決定している。 まず, 変調 される光パルスの時間波形, スペクトル波形はあらかじめ FROGによって求めておく。通常Gerchberg-Saxton法17) 時間波形とスペクトル波形におけるそれぞれの振幅が既 知かつ位相が未知の場合に位相回復に用いられる方法で あるが,ここでは位相フィルタとスペクトル波形における 位相が未知であるとして, スペクトル波形と目的の時間波 形(ここではダブルパルス波形)の振幅を拘束条件として同 様に繰り返し演算を行い, 収束值をフィルタに用いてい る. 図中 (b)が得られたFROG像, (c)および (d)が解析結果 である，概ね設計通りの位相変調が行われているが, 自己 位相変調に起因すると見られるスペクトルや時間波形の ビートが確認される.

\section{3 考 察}

上記 $2 つ の$ 実験結果より, 透過型光学素子を含む光学系内 で生じた自己位相変調は, 波形整形器の性能を著しく低下 させることがわかり，これを防ぐ意味でも反射型は有利で ある. 尚, その他の外部要素による自己位相変調の問題を 解決するためには, FROG像から光パルス波形を再構成し た結果をフィルタにフィードバックする方法, 理想的に波 形整形が行われた場合のFROG像と実験結果のFROG像の 差分をフィルタにフィードバックする方法などを用いる という対応が必要であると考えられる10,18-20).

\section{4. まとめ}

本研究では, 高強度レーザー用波形整形器および光パル ス波形計測システムを構築し, Ti:sapphire再生増幅システ ムから得られる繰り返し周波数 $250 \mathrm{kHz}$, パルス幅 $65 \mathrm{fs}, \mathrm{SLM}$ に照射される平均光強度 $0.4 \mathrm{~W}$, ピークパワー $2.4 \times 10^{7} \mathrm{~W}$ 程 度の光強度レベルまでは十分に波形整形に供する位相変 調をかけることができることを確認した。 今後は,さらに 高強度のTWレーザー等の波形整形を行うためにシステム の改良を行い,構築したシステムを用いて高強度光パルス と物質との相互作用の研究を行う予定である.

\section{参考文献}

1) G. A. Mourou, C. P. J. Barty, and M. D. Perry: Phys. Today 51 (1998) 22.

2) 熊谷寛：応用物理学会誌 67 (1998) 1051.

3) B. Pirauz, A. L. L'Huillier, and K. Rzazewski (ed): Super-Intense Laser-Atom Physics (Series B: Physics Vol.316, Plenum, New York, 1993)

4) D. Umstadter, S.-Y. Chen, A. Maksimchuk, G. Mourou, and R. Wagner: Science 273 (1996) 472.

5) T. Ditmire, J. Zweiback, V. P. Yanovsky, T. E. Cowan, G. Hays, and K. B. Wharton: Nature 398 (1999) 489.

6) M. M. Wefers and K. A. Nelson: Opt. Lett. 20 (1995) 1047.

7) A. M. Weiner, D. E. Learid, J. S. Patel, and J. R. Wullert: IEEE J. Quantum. Electron. 28 (1992) 908.

8) K. Komori, T. Asahara, T. Sugaya, M. Watanabe, and T. Hidaka: Proc. LEOS'98 1 (1998) p.59.

9) I. Brener, P. C. M. Planken, M. C. Nuss, M. S. C. Luo, S. L. Chuang, L. Pfeiffer, D. E. Leaird, and A. M. Weiner: J. Opt. Soc. Am. B 11 (1994) 2457.

10) T. Brixner, M. Strehle, and G. Gerber: Appl. Phys. B 68 (1999) 281.

11) K. Naganuma, K. Mogi, and H. Yamada: IEEE J. Quantum Electron. QE-25 (1989) 1201.

12) R. Trebino, K. W. DeLong, D. N. Fittingoff, J. N. Sweetser, M. A. Krumbugel, and B. A. Richman: Rev. Sci. Instrum. 68 (1997) 3277.

13) L. Gallmann, D. H. Sutter, N. Matuschek, G. Steinmeyer, and U. Keller: Opt. Lett. 24 (1999) 1314

14) N. Mukohzaka, N. Yoshida, H. Toyoda, Y. Kobayashi, and Tsutomu Hara: Appl. Opt. 33 (1994) 2804.

15) Y. Igasaki, F. Li, N. Yoshida, H. Toyoda, T. Inoue, N. Mukohzaka, Y. Kobayashi, and T. Hara: Opt. Rev. 6 (1999) 339.

16) R. L. Fork, C. H. Brito Cruz, P. C. Becker, and C. V. Shank: Opt. Lett. 12 (1987) 483.

17) R. W. Gerchberg and W. O. Saxton: Optik 35 (1972) 237.

18) F. G. Omenetto, B. P. Luce, and A. J. Taylor: J. Opt. Soc. Am. B 16 (1999) 2005

19) D. Yelin, D. Meshulach, and Y. Silberberg: Opt. Lett. 22 (1997) 1793.

20) M. Shiozawa, M. Suzuki, M. Sato, K. Takasago, and F. Kannari: Technical Digest of CLEO/Pacific Rim '99, Seoul, 30 Aug.-3 Sep. (1999) p.670. 